\title{
BUILDING A ROBUST HR AUTOMATION SYSTEM AT MANIPAL HEALTH ENTERPRISES PRIVATE LIMITED, BENGALURU
}

\author{
DR. A.R. VIJAYA CHANDRAN
}

Associate Professor, Christ(deemed to be University), Bangalore, Karnataka, India

\begin{abstract}
Entrepreneurship is the pursuit of opportunity without regard to resources currently controlled (Eisenmann, 2013). It is often seen as the life source of an economy. To support this life source should be objective of any government. In its journey to development, the Indian government has in recent years implemented and amended many a legislation to improve the ease of doing business in the country. This paper attempts to understand the effectiveness of the same by conducting a study on startups in the IT sector of Bengaluru. By extensive literature review and interview of startup founders this paper aims to classify the major compliance issues faced by startups and identify the reasons for these issues. As a result of this study, five labor laws were identified to cause major compliance issues. Questions related to these acts and particular issues were compiled to formulate a questionnaire which was administered to a sample population with the help of a semi- structured interview. Such a structure allowed to get specific information as well as allowed an in-depth discussion regarding the topic. Some reasons identified as a result of the interview include lack of awareness, nature of the employees, gig economy, etc. The paper has tried to capture the opinions of the target group regarding the compliance environment in Bengaluru.
\end{abstract}

KEYWORDS: Compliance, Startups, Labor Laws, Ease of Doing Business, Gig Economy

Received: Jun 09, 2020; Accepted: Jun 29, 2020; Published: Aug 06, 2020; Paper Id.: IJMPERDJUN2020641

\section{INTRODUCTION}

With many a government scheme and policy supporting entrepreneurship in the country, the number of start-ups is increasing drastically. Even though policy measure such as self-attestation for a period of 5 years support these entities with regard to compliance; it is observed that they are still prone to legal violations. One major reason might be that such organizations may not have the financial capability or may even lack the interest to hire a full-time human resource or legal professional. The aim of this study is to understand the potential compliance issues faced by startup in the IT sector of Bengaluru, India in such a way that the readers of this thesis will be better informed of compliance issues.

Karnataka and in particular Bengaluru has been chosen for this study because of Karnataka's reputation as a top performer among Indian states in terms of its practices in Startup Policy and Bengaluru's position as the only Indian city to be ranked in the top 20 by the Global Startup Ecosystem Report for 2019. The IT sector in particular has been given focus because it is one amongst the most affected sectors in the era of digitization and automation. A high growth potential sector such as has a high chance of being the next big strength to the Indian economy. Thus, this paper seeks to understand the compliance environment of startups engaged in Information technology and operating in one of the most startup friendly ecosystems of the country.

The opinions of 15 startup founders and Human Resource professionals working with startups have been 
collected by way of a semi structured interview conducted primarily over telephonic interviews.

\section{REVIEW OF LITERATURE}

The term 'start-up' announced by the Hon'ble Prime Minister, Narendra Damodardas Modi on 15th August, 2015 has created a ripple in the minds of India's youth and brought along a spree of enterprises that has invigorated the economy of the nation. The 'Startup India' campaign announced by the Prime Minister has not only made waves in the Indian business scenario but portrayed its intent to promote and support the young and budding entrepreneurs of the nation and even so to unleash the talent in the youth of the country. Be in technological innovations or service sector developments, the nation is witnessing something unusually new and novel, budding businesses which not only make money but which also makes the lives of people easier (Pandey, 2019).

According to the NASSCOM report of 2019 India is home to almost 7700 startups and more than 210 active incubators/ accelerators (NASSCOM, 2019). The large population in India provides a fertile ground of ever- increasing demand for which a competitive business environment is created; which is further fostered by an emerging startup ecosystem (Jain, 2016). The Government of India and Regulatory bodies have responded swiftly and positively to this high a spike in entrepreneurship. Recently, the Department for Industrial Policy and Promotion (DIPP) or its Department of Promotion for Industry and Internal Trade (DPIIT) as it is called now, under the Ministry of Commerce, vide its notification dated 19th February 2019 has revolutionized the world of Startups by introducing the new definition of Startups and modified tax structures.

In this notification, the conditions for eligible start-ups have been relaxed by extending the time period of recognition from seven to ten years from the date of incorporation. The ceiling limit of maximum turnover in any financial year (FY) is also increased from INR 250 million to INR 1 billion. The notification also aims to extend relief from section 56(2)(viib) of the Act by excluding investments received from non-residents, venture capital entities and certain listed companies from the prescribed threshold limit of INR 250 million in respect of share capital and share premium. The earlier condition to submit the valuation report as per Rule 11UA of the Income-tax Rules, 1962 (Rules) and obtain approval from the Central Board of Direct Taxes (CBDT) has been removed; instead, a declaration in a specified form shall be sufficient. In brief, the new notification aims to facilitate the Government of India's (GoI) objective of ease of doing business in India and simplify the tax environment to catalyze the growth of start-ups in the country ( PwC, 2019).

A company should satisfy the following criteria to be considered eligible for DPIIT startup recognition: A) The company age: Period of existence and operations should not be exceeding 10 years from the Date of Incorporation. B) Company Type: Incorporated as a Private Limited Company, a Registered Partnership Firm or a Limited Liability Partnership. C) Annual Turnover: Should have an annual turnover not exceeding Rs. 100 crores for any of the financial years since its Incorporation. D) Original Entity: Entity should not have been formed by splitting up or reconstructing an already existing business. E) Innovative \& Scalable: Should work towards development or improvement of a product, process or service and/or have scalable business model with high potential for creation of wealth \& employment. As at the time of this thesis, the DPIIT has recognized 27,066 startups in the country (Department for Promotion of Industry and Internal Trade, 2020). 


\section{OBJECTIVES OF THE STUDY}

\section{The Following are the Objectives of This Study:}

- To classify potential compliance issues under major acts for the benefit of entrepreneurs.

- To identify the major reasons for compliance issues faced by startups during their journey from incorporation to a period of 5 years.

\section{RESEARCH METHODOLOGY}

\subsection{Statement of the Problem}

To identify the major reasons for compliance issues faced by start-ups in their initial years in the IT sector of Bengaluru, India

\section{SCOPE OF THE STUDY}

- Initial years- As per the Department for Industrial Policy and Promotion (DIPP)in its notification dated 19th February 2019; an entity can be classified as a startup up-to ten years from the date of its incorporation. For the purpose of this study; initial years would mean up to 5 years, as this is the maximum validity of self-attestation.

- Considering the number of Acts applicable to the population along with the literature review; only 5 labor laws and its related notifications have been chosen for Anchoring the study. They are:

The Karnataka Shops and Commercial Establishments Acts, 1961

The Employees' Compensation Act, 1923

The Contract Labour (Regulation and Abolition) Act, 1970

Employees' Provident Fund and Miscellaneous Provisions Act, 1952

The Payment of Gratuity Act, 1972

- With relation to the time period of this study, it is limited to a period of 6 months starting from September 2019 to February 2019

- The study is limited to the city of Bengaluru, India

- The study is conducted only on the IT sector

- The study does not intent to create a model but is intended only to identify the possible major pitfalls that might happen in relation to the above-mentioned laws.

\subsection{Research Design}

Due to a lack of prior work which is specific to this study; an exploratory research was carried out

\subsection{Research Type}

A qualitative research framework has to be used to identify the major issues in question.

\section{DATA COLLECTION}




\subsection{Primary Data}

This data is to be collected by way of semi-structured interview; involving questions pertaining to 5 specific Acts along with open- ended questions to understand the situation in depth. This data will be used to analyze the result of the study.

\subsection{Secondary Data}

'This data is collected from various research articles, government reports and subject- specific books as is detailed in the literature review. This data is only used to prepare the questionnaire.

\section{POPULATION}

The population includes all the startups in the IT sector of Bengaluru, Karnataka

\section{SAMPLING TECHNIQUE}

Since the exact number of start-ups in Bengaluru is uncertain, a non-probability sampling method is employed within which a convenient sampling technique is used. A self-completed questionnaire by means of telephonic interview has been employed for data collection.

The respondent had an option of answering anonymously or giving their name and organization name which would be used only for research purposes.

\subsection{Sample Size}

The data has been collected from 15 respondents who are either startup founders or HR professionals employed with startups.

\section{LIMITATIONS}

- With regard to the time constraint the sample size has been limited to 15 respondents.

- The study will concentrate on the specified Acts and any notifications applicable on them until January 2020 only.

- The study is restricted to the IT sector in Bengaluru.

\section{ANALYSIS}

Each of the scaled questions have been answered as follows:

\subsection{General Questions:}

Figure 1 shows As per the data, the youngest startup was 3 months old while the oldest has completed 4 years since inception. Most of the respondents (i.e., $26.7 \%$ of the sample) have completed four years since inception.

Figure 2 shows Registration under the scheme is possible only if the startup meets the five conditions specified by the DIPP. As per the same, $53.3 \%$ of the sample or 8 startups have been registered while the other $46.7 \%$ or 7 startups have not been registered

Figure 3 shows it is found that there is a lack of knowledge about the labor law benefits accruing from registration of startups. Only $53.3 \%$ of the sample has knowledge about the said benefit.Some other insights are: - 
Even if a startup is registered under the act, it does not automatically get all the benefits attached. E.g. Even after registration, the startup has to again fulfill certain conditions if it has to be eligible for income tax exemption.

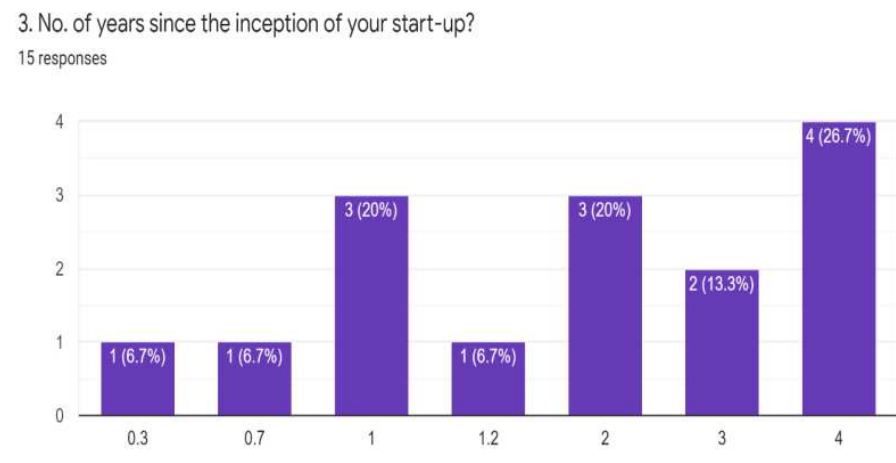

Figure 1

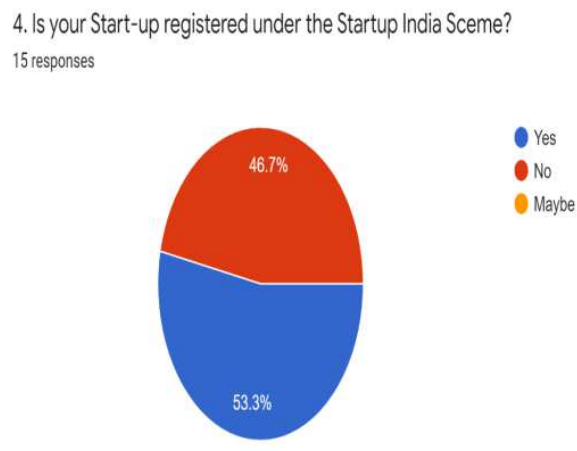

Figure 2

5. Did u know that you can self-certify under 6 labour laws for a period of up to 5 years? 15 responses

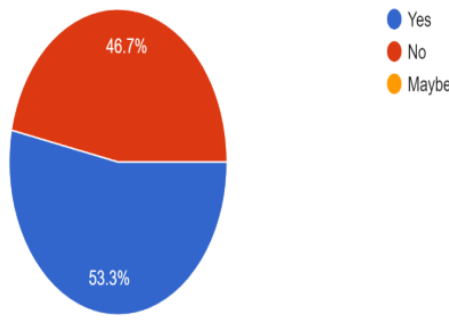

Figure 3

\subsection{Employees' Provident Fund and Miscellaneous Provisions Act, 1952:}

Figure 4 shows the general opinion is a "No" because:

- Startups usually employ a young, most often a millennial workforce that prefers cash in hand than in a PF account. That way they may spend as they wish or invest in better investment opportunities. 
- Startups tend to operate under bare minimum compliance as during their initial years, the focus is on survival. Fare treatment of employees is also given priority but startups generally do not go for unnecessary paperwork nor additional administrative costs- from hiring a consultant or another employee for the same.

Figure 5 shows the common answer is a "yes" because:

- Startups generally go for a contract employee because of the ease of hire and fire and sometimes due to benefits like requirement of lesser pay. Because of this particular fact, startups generally do not hire "contract labor" as such

Insight: In order to overcome this particular hurdle, startups hire "interns". This change in nomenclature from "contract labor" to "interns" allow startups to reap in the benfits of contract employment without the liabilities of the same. E.g. Hiring an intern for 3 months below the minimum wage prescribed.

Figure 6 shows the general answer is "Yes" because:

- The aim of a startup is survival in its initial years and this would deviate from that aim due to additional expenses

- Even the employees will not prefer additional PF as they would want more cash in hand.

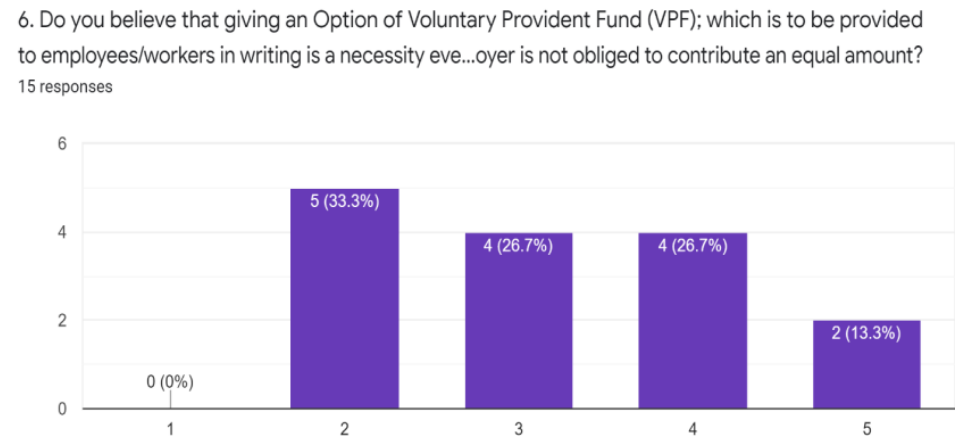

Figure 4

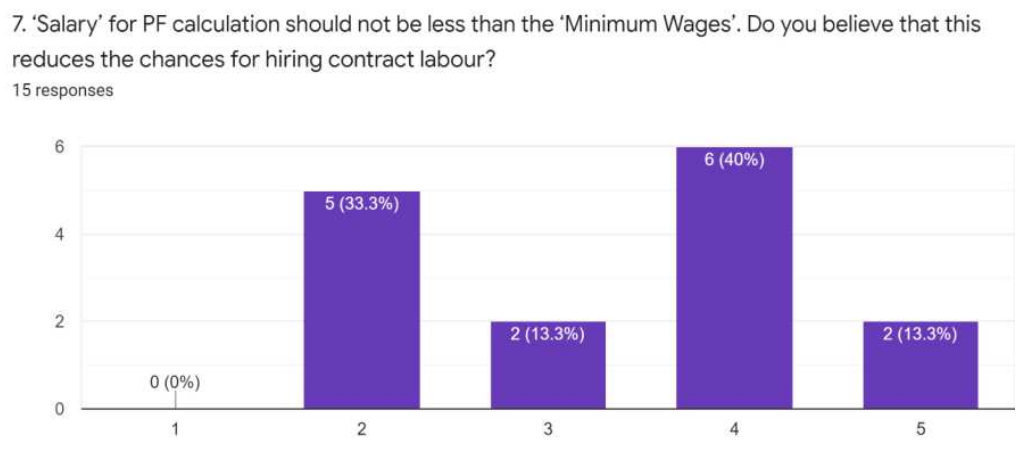

Figure 5 


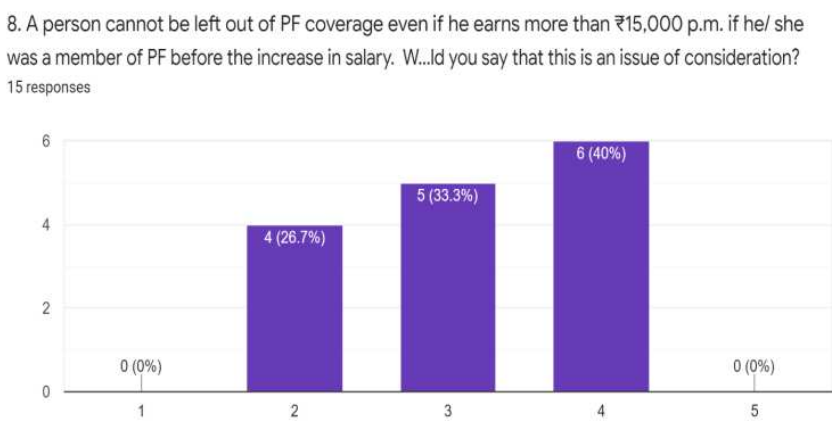

Figure 6

\subsection{The Employees' Compensation Act, 1923:}

Figure 7 shows $86.7 \%$ of the sample or 13 startups have reported no accidents while the other $13.3 \%$ or 2 startups have reported accidents during the course of employment. Hence, this is not a major issue of consideration.

Figure 8 shows the general answer is "yes" because:

- Startups generally outsource compliance and this would increase the cost of such service.

- If not outsourced it would increase the administrative charges as the company might have to spare or hire a separate employee for such activities and hence deviating from their purpose of survival

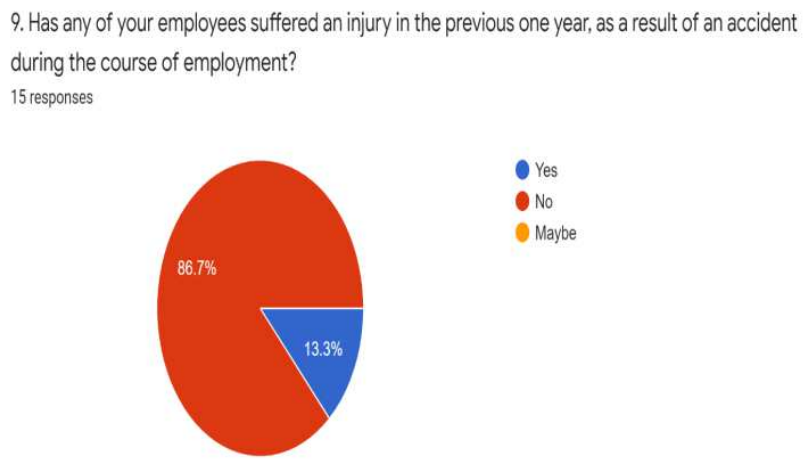

Figure 7

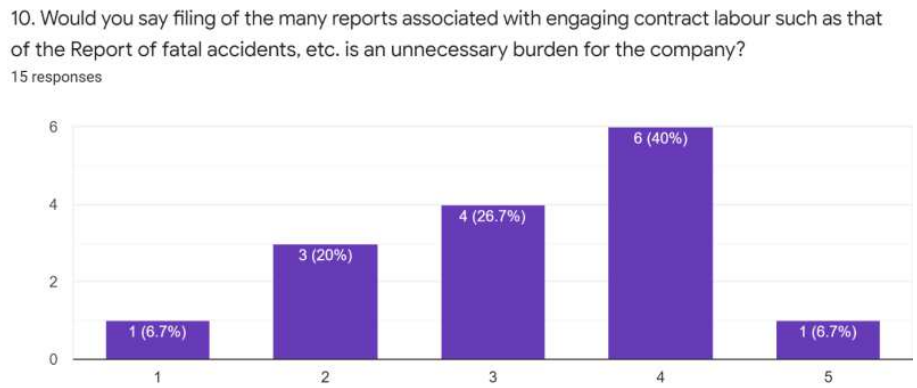

Figure 8 


\subsection{The Payment of Gratuity Act, 1972:}

It is observed that there is a conflict of opinion between "neutral" and "yes" because:

1) Startups agree that such payment should be made, but they do not believe an employee would stay with them for more than 5 years in the current age or they have not experienced such an issue as of now

2) Generally, companies keep a separate funds for the same or take an LIC policy and pay the premium, but it is observed that HR professionals hired in such startups focus more on the hiring and retaining part of the function and often are unaware or ignorant of keeping such funds. This most often causes problems.

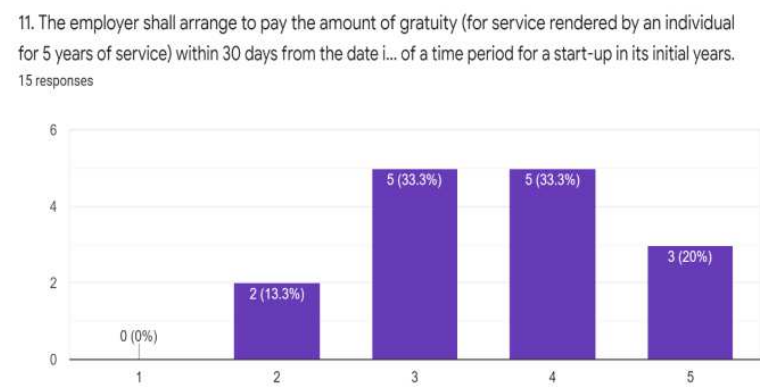

Figure 9

\subsection{The Karnataka Shops and Commercial Establishments Acts, 1961:}

Figure 10 shows it is observed that there is a major opinion of "strongly agree "because:

- Startups believe in flexible hours as long as the employee ensures efficiency in performing tasks

- The jobs in a startup will primarily be task based and not time based. Hence, some days the employee may work 9 hours in a day while on another he/ she may work only 4 hours. The employees usually balance these timings.

Figure 11 shows the general opinion is "yes" because of the additional cost involved.

Insights: Usually employees don't claim such benefits because of their "learning" mentality during the job and startups most often give additional benefits only if employees go to additional lengths such as working on weekends and other public holidays. That benefit too, is paid there and then.

Figure 12 shows Even though there is a mixed opinion, because of a matching increase in the opinion of "strongly agree" and "agree" we can say that, such a limit on maximum working hours does hinder a startups performance.

- Due to the nature of startups there might be some weeks with additional workloads and some with lesser workloads. So, a fixed maximum time may hinder their potential

- Because of the task orientation of employees, there is a chance of these time limits being ignored.

Figure 13 shows There is an equal distribution between "yes" and "no" because:

- All respondents were of the opinion that such special permission was a necessity for ensuring women safety

- Most of them were also of the opinion that additional permission would increase the administrative hassle 
Insights: This question has become irrelevant from $20^{\text {th }}$ November 2019, following the Karnataka governments most recent notification stating that women can be employed in the night shifts without getting special permission. The employer still has to ensure specific criteria are met and that there is a written consent from the women employees who wish to work at night.

Figure 14 shows the general opinion is "no" because:

- Startups offer flexible working hoursto its employees. If the employee meets expectations or fulfills his tasks within said time, they are free to schedule leaves as per the existing conditions of work.

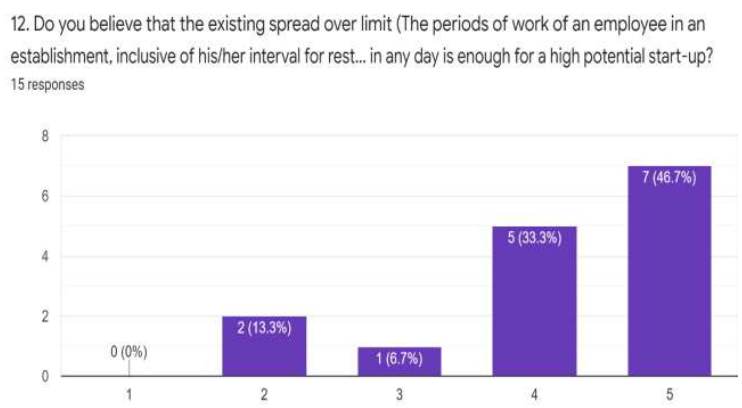

Figure 10

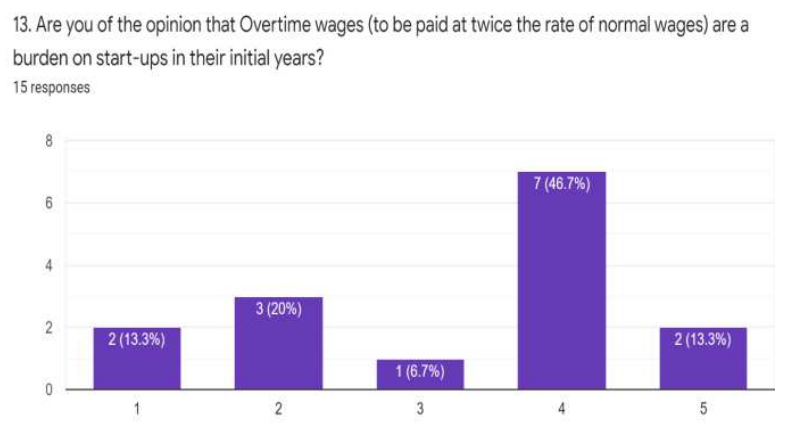

Figure 11

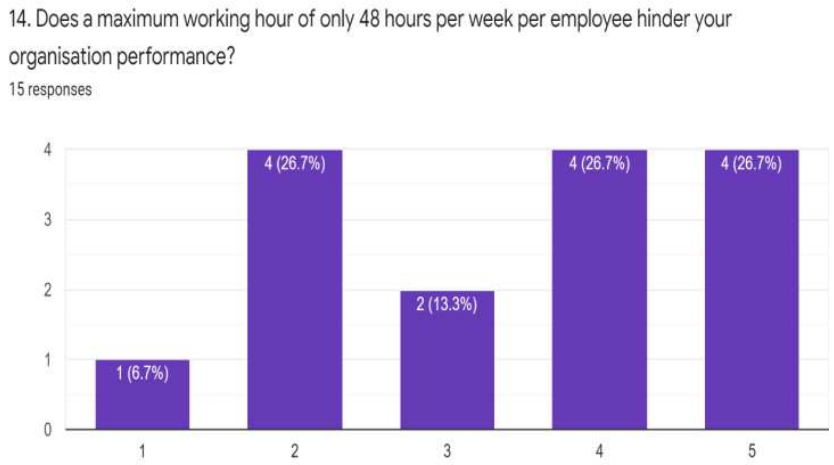

Figure 12 


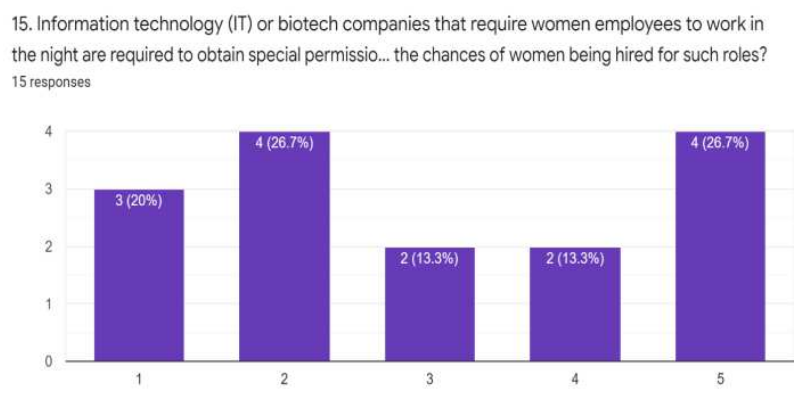

Figure 13

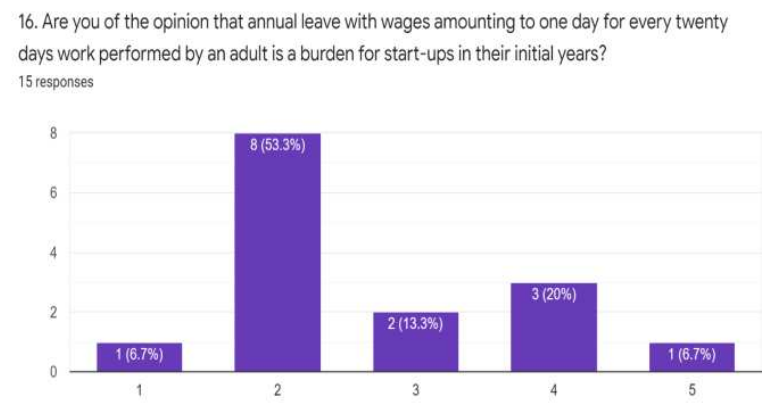

Figure 14

10.6. The Contract Labour (Regulation and Abolition) Act, 1970:

Figure 15 shows $60 \%$ of the sample or 9 startups employee contract labor while the remaining 6 or $40 \%$ do not employee contract labor as such.

Insight: Most of the startups do employee "interns".

Figure 16 shows the general answer is "no, it does not limit the opportunities of hiring contract labor". This is because:

- Most often, such employees are knowledge workers who choose their own clients. So provision of high salary or similar conditions of service for such labor is not an issue of consideration for startups.

- More often, it is the quality of work that is given importance over the nature of employment in a startup.

Figure 17 shows the general answer is "yes" because of the additional administrative cost incurred.

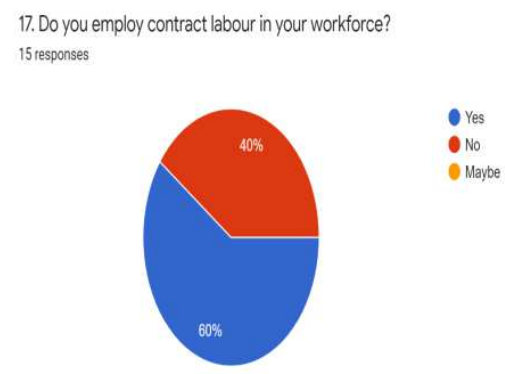

Figure 15 


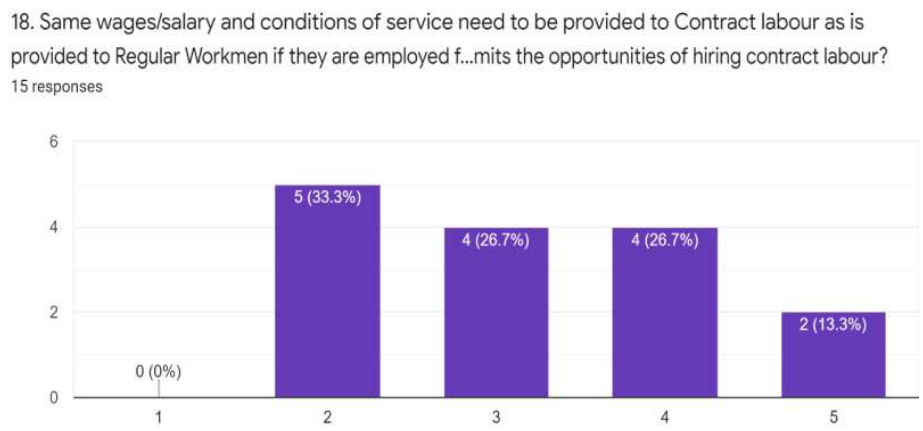

Figure 16

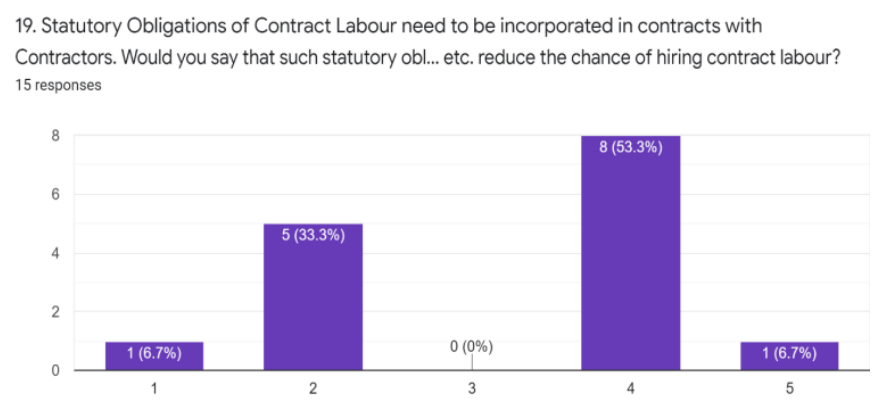

Figure 17

\section{FINDINGS}

The following are the findings of this study:

- Forthepurposes of this study the major compliance issues were classified on the basis of the following acts as per literature review:

The Karnataka Shops and Commercial Establishments Acts, 1961

The Employees' Compensation Act, 1923

The Contract Labor (Regulation and Abolition) Act, 1970

Employees’ Provident Fund and Miscellaneous Provisions Act, 1952

The Payment of Gratuity Act, 1972

During the course of the study, it has been found that start-ups indeed face issues with these Acts and they have sometimes taken measures like change in nomenclature to avoid the hassle.

The following are the major reasons for compliance issues faced by startups during their journey from incorporation to a period of 5 years:

- Lack of awareness: It is observed that there is a general lack of awareness with respect to the benefits of registration of start-ups. 
- Aim of a Start-Up in Initial Years: The aim of a start-up in its initial years and anything deviating from that aim including additional administrative costs is most often avoided by employers. Thus, start-ups most often go for bare minimum compliance.

- Nature of Employees: It is observed that most start-up employees are millennials who join such an organisation with the dual objective of learning and long-term monetary benefits. Thus, they prefer more cash in hand than employer led investments

- Change in Nomenclature: Due to many obligations accrued out of employing contract labour, it is observed that most organisations change the term "contract labour" into "interns" wherein such interns are engaged from anywhere between 3 months to 1 year. The employer gets all the benefits of contract labour and accrue none of the liabilities.

- Shifting Legislation: Due to the need for increasing the ease of doing business, it is observed that the central and state governments are actively amending as well as creating new legislature. Some examples are: -

As per the latest notification by the Karnataka Government, dated $20^{\text {th }}$ November 2019 , women employees can now be employed in night shifts without getting prior permission. But the employer still has to get a written consent from such employee and also ensure other specifications like security.

The Wage Code Bill of 2019- The provisions of the Minimum Wages Act and the Payment of Wages Act used to apply only to workers drawing wages below a particular ceiling and working in scheduled employments only. However, under the Code, the minimum wages and the payment of wages provisions cover all establishments, employees and employers as defined unless specifically exempt (the member of the Armed Forces of the Union and apprentice engaged under the Apprentices Act, 1961 are specifically excluded from the definition of employee)

- Gig economy- Because of a rising labour marketcharacterized by the prevalence of short-term contracts or freelance work as opposed to permanent jobs and a rise in demand of knowledge workers; it is observed that the duration of employment in most start-ups is comparatively lesser as compared to established organisations and there is a lack of long term perspective by the employer with regard to the employees. Hence, statutory benefits such as gratuity are given less focus.

\section{SCOPE FOR FUTURE RESEARCH}

Future research can be conducted on

- Other relevant labor laws and compliance issues concerning them.

- A comparison between ease of compliance between the existing labor laws and new Wage Code Bill of 2019

- A study on why there is a reluctance among founders for registration of their startups.

\section{CONCLUSIONS}

\section{REFERENCES}

1. PwC. (2019, February 24). Retrieved from https://www.pwc.in: https://www.pwc.in/assets/pdfs/news-alerttax/2019/pwc_news_alert_24_february_2019_govt_widens_definition_of_start_ups.pdf. 
2. Ainger, N. (2017, July). REGULATORY TECH. Global Finance.

3. Besley, T., \& Burgess, R. (2004). Can Labor Regulation Hinder Economic Performance? Evidence from India. The Quarterly Journal of Economics, 119(1), 91134.

4. Botero, J. C., Djankov, S., Porta, R. L., Lopez-de-Silanes, F., \& Shleifer, A. (2004). The Regulation of Labor. The Quarterly Journal of Economics, 119(4), 13391382.

5. CB Insights Report. (2017). UNICORN TRENDS REPORT.

6. Chaurey, R. (2015). Labor Regulations and Contract Labor Use:. Journal of Development Economics, 224232.

7. Christopher, N., \& Bansal, V. (2018, Jun 18). Indian startups still don't take data privacy seriously. Srikrishna Committee may change it soon. The Economic Times. Retrieved from https://m.economictimes.com/small-biz/startups/newsbuzz/indianstartups-still-dont-take-data-privacy-seriously-srikrishna-committee-may-change-soon.

8. CHATTERJEE, KOUSIK, and SABUJ DASGUPTA. "LITERATURE REVIEW OF INFORMATION SEEKING BEHAVIOR OF FARMERS IN INDIA." International Journal of Humanities and Social Sciences (IJHSS) 5.5 (2016): 163182.

9. Kiong, Tan Wee, et al. "A Cross Sectional Study on the Awareness and Knowledge of Patient's Rights Among Medical Students in Malaysia." International Journal of Nursing and Health Science 7.1 (2020): 12.

10. SINGH, NISHU, and AS HUTOS H. GAUR."IMPACT OF TRAINING AND DEVELOPMENT IN INDIAN HEALTH CARE."International Journal of Human Resources Management (IJHRM). 

